\title{
Milk yield, residual milk, oxytocin and cortisol release during machine milking in Gir, Gir $\times$ Holstein and Holstein cows
}

\author{
João Alberto NEGRÃOa*, Pierre-Guy MARNET ${ }^{\mathrm{b}}$ \\ a USP/FZEA, Cx. Postal 23, 13630-970, Pirassununga/SP, Brazil \\ b UMR production du lait, INRA/ENSAR, Rennes, France
}

(Received 26 January 2005; accepted 14 October 2005)

\begin{abstract}
This study evaluated the effect of exclusive machine milking on oxytocin (OT) and cortisol (CORT) release, and on milk yield and residual milk in Gir (group Gir), Holstein (group $\mathrm{Hol}$ ) and crossbred animals (group GirHol). Six animals from each group were submitted to experimental milkings. As expected, milk yield was significantly higher in the Hol group than in the groups GirHol and Gir, and group GirHol produced more milk than the Gir group. In contrast, all groups exhibited significant but similar levels of OT, although OT increased more rapidly during milking for the groups Hol and GirHol than for the Gir group. In addition, CORT levels measured during and after milking were significantly influenced by the group. The Gir group showed higher levels of CORT than the groups GirHol and Hol. The lower performances of the Gir breed can not be explained by a less efficient milk ejection reflex because all cows studied released enough OT and had an effective milk ejection.
\end{abstract}

zebu / crossbred / milking / oxytocin / cortisol

\section{INTRODUCTION}

Gir cows are well adapted to high temperature conditions, are resistant to some tropical diseases [1,2], and have been continuously selected for milk yield in Brazil $[3,4]$. However, many farmers have used crossbred Gir (Bos indicus) and Holstein cows (Bos taurus) to improve dairy production in the Brazil $[3,4]$, and this crossbreeding programme is considered to be a success and economically viable [5]. Consequently, many specialised dairy farmers have dairy cows with varying percentages of Gir blood [5]. However, Gir cows and their crossbred offspring are not well-adapted to machine milking, and thus are often replaced by Holstein cows.
Normally, machine milking provokes an oxytocin release and milk ejection via neuroendocrine reflex, but machine milking could sometimes cause stress and entail a significant reduction in milk yield [6-8]. As a result, some farmers allow crossbred cows to be suckled by their calves, because these cows produce more milk than those submitted to exclusive machine milkings [9-11]. Obviously, this mixed management increases the labour of milkers and thus many farmers wean calves at birth and submit both Gir and Gir $\times$ Holstein cows to exclusive machine milking, except for a short colostral period during suckling, as is done with dairy Bos taurus cows [7, 12, 13]. Indeed, the immediate separation of the cow and

\footnotetext{
* Corresponding author: jnegrao@usp.br
} 
calf overlooks the fact that weaning inhibits OT and PRL release [8], and is accompanied by a significant decrease in milk production $[7,8]$. This contributes to the belief that Gir cows and their crossbred offspring can not adapt easily to machine milking.

In other countries, some Bos indicus breeds are also susceptible to lactation failure $[14,15]$ and retain high volumes of residual milk [15]. Disturbance of milk ejection can be attributed to a selective inhibition of OT release from the hypophysis gland as described after weaning $[8,16]$; in this case, normal milk ejection can be established after OT administration [6]. Alternatively, it can be associated with milking stress and is characterised by high CORT and noradrenalin levels [16]; in this case, even OT administration did not restore complete milk ejection [6]. Recently, it was reported that Gir $\times$ Holstein cows exhibit a similar pattern of OT release during exclusive machine milking as during suckling/ milking management [11], which suggests that crossbred Gir $\times$ Holstein cows could be successfully submitted to exclusive machine milking. Taking this into account, Gir cows, Gir $\times$ Holstein cows (F3) and Holstein cows were used to compare their response when submitted to exclusive machine milking by means of oxytocin (OT) and cortisol (CORT) assay, and milk yield and residual milk were recorded during early-lactation.

\section{MATERIALS AND METHODS}

The experiment was carried out at the beginning of the summer (the rainy season), using 6 Gir cows (Bos indicus; group Gir), 6 Gir $\times$ Holstein cows $(1 / 8$ Bos indicus $\times 7 / 8$ Bos taurus; group GirHol) and 6 Holstein cows (Bos taurus; group Hol) from the same experimental farm. Experimental cows had similar lactation number $(3.0 \pm$ $0.4,3.0 \pm 0.3$ and $2.5 \pm 0.5$ for Hol, GirHol and Gir cows, respectively) and lactation days $(34 \pm 4,36 \pm 3$ and $34 \pm 5$ for Hol, GirHol and Gir cows, respectively), however, the three groups of cows had different production levels at the beginning of the experiment $(27.1 \pm 3.0,20.2 \pm 4.1$ and 12.3 $\pm 2.5 \mathrm{~kg}$ for Hol, GirHol and Gir cows, respectively).

All cows had free access to water and vitamin/mineral mix (Purina Agribrands, Campinas, São Paulo, Brazil). Before each milking, each cow received corn silage and a mixture of grain (corn, extruded whole soybeans, soybean hulls and cotton seed) according to their production in their individual tie-stall [17]. This diet was assessed weekly, and when necessary, additional mixture of grain and silage were offered to provide adequate nutrients for milk production [17]. All groups had access to pasture (Panicum maximum) for $8 \mathrm{~h}$ daily. The quantity and quality of the available pasture was evaluated biweekly and estimated as an excess of nutrients for lactating cows [17].

\subsection{Milking}

In order to avoid any influence of previous milking management on the present experiment, we used cows that had been submitted to exclusive machine milking in their previous lactations.

All cows were milked twice daily (at 6 and $18 \mathrm{~h}$ ). Milking machine parameters were constant throughout the experiment. The cows were milked in a double 4-stall parallel milking parlour. The settings for the low line milking machine (Westfalia Elk Grove Village, Illinois, USA) were a vacuum of $45 \mathrm{kPa}$, a pulsation ratio of $70: 30 \%$, a pulsation rate of 60 cycles per min and clusters (No. 40380000202, Westfalia, Campinas, São Paulo, Brazil) and silicon liners (No. 702799330006, Westfalia, Campinas, São Paulo, Brazil) were used. These milking machine parameters are generally used in Brazil for Gir and GirHol milk cows.

Milking routine included teat cleaning and drying, and foremilk hand milking on a back cup for assuring the absence of milk flocks, as pre-stimulation practices during 
approximately $1 \mathrm{~min}$. Teat cups were attached thereafter and manually detached after visual observation of milk flow cessation. Machine stripping was not applied. The milking routine was constant and the same person performed all experimental milkings.

\subsection{Milk yield and residual milk}

Milk yield (milk obtained from machine milking) was weighed at both milkings on days $39,40,41,42,43,44$ and 45 of lactation. Ten minutes after the cluster removal, each experimental cow received 5 UI of OT (Ocitocina, Univet, São Paulo, Brazil) in the jugular vein and the residual milk was weighed (model 2090, accuracy $\pm 5 \mathrm{~g}$, Toledo, São Paulo, Brazil) after a supplementary machine milking. Machine stripping to remove residual milk was not carried out for both normal and residual milking. The weight of residual milk was determined at morning and evening milkings on days 39, 42 and 45 of lactation. Since experimental groups had different production levels, we transformed the weight of residual milk into the percentage of total milk (milk yield + residual milk = $100 \%$ total milk).

In order to classify milk ejection within each experimental group, we used the percentage of residual milk of all animals that had incomplete milk ejection. It was then possible to identify two distinct classes of cows: impaired milk ejection-cows that presented larger values of residual milk ( $>8 \%$ ); and effective milk ejection - cows that presented lower values of residual milk $(\leq 8 \%)$.

\subsection{Blood samples and hormone analyses}

A silicon catheter (model 2180, diameter $2 \mathrm{~mm}$, Nutricath, Vygon, New Jersey, USA) was implanted into the jugular vein of cows $72 \mathrm{~h}$ before the first experimental milking on day 39. Blood samples were taken at the morning milking on days 39 , $40,41,42,43,44$ and 45 of lactation, both before (at $-3 \mathrm{~min}$; basal levels) and after beginning milking (at 1, 2, 3, 5, 7, 10, and $13 \mathrm{~min})$. The samples were collected in chilled heparinised tubes and immediately centrifuged at $4{ }^{\circ} \mathrm{C}$ and $3000 \mathrm{~g}$ for $15 \mathrm{~min}$. Plasma was preserved at $-20{ }^{\circ} \mathrm{C}$ until analysis. Plasma concentrations of OT were measured by an enzyme immunoassay (EIA) method [18] and plasma concentrations of CORT were determined using the EIA kit (DSLab, Webster, Texas, USA). The inter-assay coefficients of variation (CV) were $6.8 \%$ and $8.6 \%$ for OT and CORT respectively, and intra-assay $\mathrm{CV}$ were $9.9 \%$ and $9.1 \%$ for OT and CORT, respectively. The limits of detection were $1.2 \mathrm{pg} \cdot \mathrm{mL}^{-1}$ and $0.35 \mathrm{ng} \cdot \mathrm{mL}^{-1}$ for OT and CORT, respectively.

Total values of OT ( $\mathrm{pg} \cdot \mathrm{mL}^{-1}$ for $\left.13 \mathrm{~min}\right)$ and CORT (ng. $\mathrm{mL}^{-1}$ for $13 \mathrm{~min}$ ) released were obtained by calculating the surface under the curve from 1 to 13 min after subtracting the basal levels measured at $-3 \mathrm{~min}$.

\subsection{Statistical analysis}

The SAS software [19] was used for evaluating the results by means of analysis of variance, Student $t$-tests and NewmanKeuls tests. The significant probability level was set at $P<0.05$, and all values presented in this work are given as the mean \pm standard error of the mean.

Statistical analysis was conducted using the mixed procedure. The analysis of hormone release took into account group (as the main factor), cow identity (as a random effect nested within group), day of milking and time of sampling (as a repeated measure), and interaction between group and time of sampling. A similar model (excluding time of sampling) was used for the analyses of milk yield, residual milk and total hormone release. The relationships between milk yield, residual milk and total hormone release were evaluated by Pearson correlation coefficients within cows, and between cows within each group. 

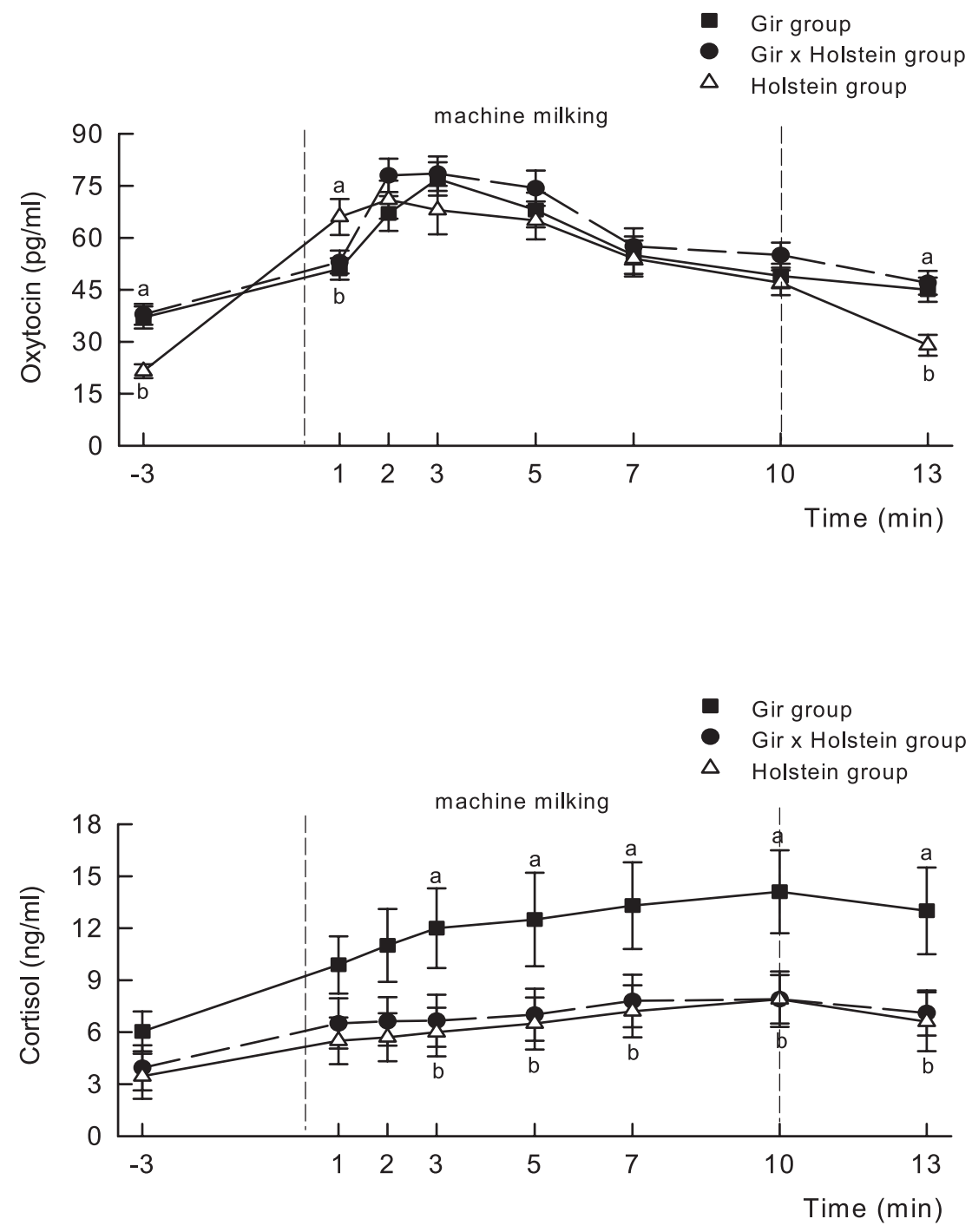

Figure 1. Oxytocin and cortisol levels (mean \pm standard error of the mean) before, during and after machine milking in Gir, Gir $\times$ Holstein and Holstein cows. Pre-stimulation was carried out before milking (from -1 at $0 \mathrm{~min}$ ). Teatcups were attached at $\min 0$ and detached after visual cessation of milk flow. Means with different letters differ between groups at $P<0.05$.

\section{RESULTS}

Basal levels of OT were affected by group. The GirHol and Gir cows having higher levels of OT than the Hol cows (Fig. 1). For all groups, OT levels measured during milking were significantly higher than basal levels. The total amount of OT released was not significantly influenced by group (Fig. 2).

However, OT levels at $1 \mathrm{~min}$ were significantly higher $(P=0.02)$ for the Hol 

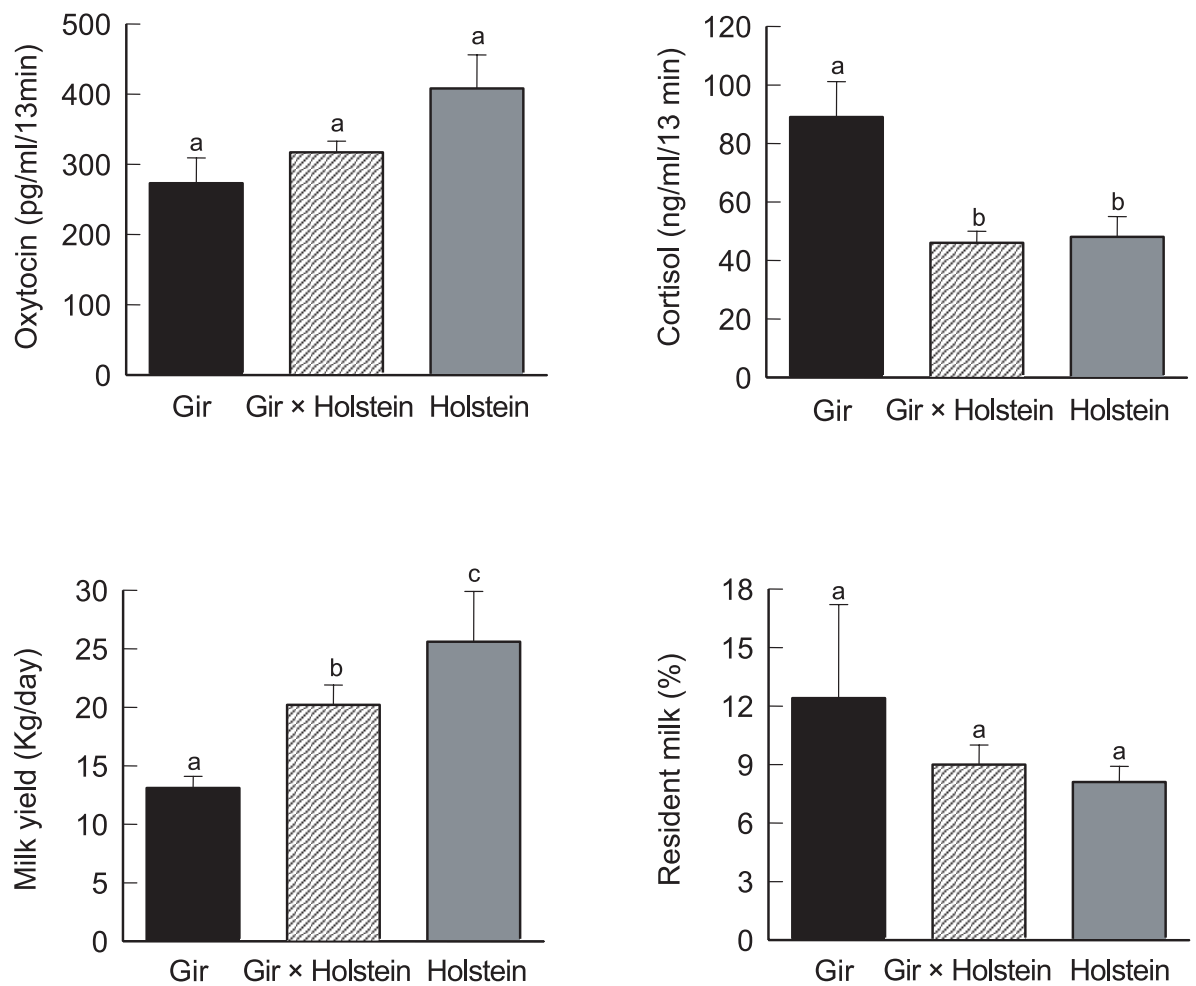

Figure 2. Total of oxytocin and cortisol released, milk yield and percentage of residual milk (mean \pm standard error of the mean) measured during machine milking of Gir, Gir $\times$ Holstein and Holstein cows. The means were calculated on days 39,42 and 45 of lactation. The weight of residual milk was calculated as percentage of total milk (milk yield + residual milk $=100 \%$ total milk). The total amount of hormone released was calculated as the surface under the curve (measured from 1 to $13 \mathrm{~min}$ and corrected for basal levels of each hormone at $-3 \mathrm{~min}$ ). The means with different letters differ between groups at $P<0.05$.

group than the other groups, although there were no differences $(P=0.29)$ between cow groups from 2 to $10 \mathrm{~min}$. A peak of OT was observed at 2 min for the Hol and GirHol groups and at 3 min for the Gir group (Fig. 1).

While the groups Hol and GirHol exhibited similar levels of CORT, the Gir group showed significantly higher levels of CORT when compared to the other groups. The total amount of CORT released by the Gir cows was significantly higher than that released by GirHol and Hol cows (Fig. 2).

As expected, milk yield was significantly higher for the Hol group (25.6 \pm $4.3 \mathrm{Kg} \cdot \mathrm{d}^{-1}$ ), followed by the GirHol group $\left(20.2 \pm 1.7 \mathrm{Kg} \cdot \mathrm{d}^{-1}\right)$ and was the lowest for the Gir group $\left(13.1 \pm 1.0 \mathrm{Kg} \cdot \mathrm{d}^{-1}\right)$ (Fig. 2). Although the Gir group appeared to retain a higher percentage of residual milk (12.4 \pm $4.8 \%$ ) compared to the GirHol and Hol groups $(9.0 \pm 1.0$ and $8.1 \pm 0.8 \%$, respectively), there were no significant differences between groups $(P=0.16)$. The duration of milking was significantly shorter $(P=0.04)$ for the Hol group $(8.2 \pm 0.5 \mathrm{~min})$ when compared to the groups GirHol $(10.0 \pm 0.5 \mathrm{~min})$ and Gir $(10.1 \pm 0.2 \mathrm{~min})$. This demonstrates that the mean milk flow differed significantly $(P=0.03)$ between groups $(1.6 \pm$ $0.09,1.1 \pm 0.04$ and $0.6 \pm 0.05 \mathrm{~L} \cdot \mathrm{min}^{-1}$ for Hol, GirHol and Hol groups, respectively). 

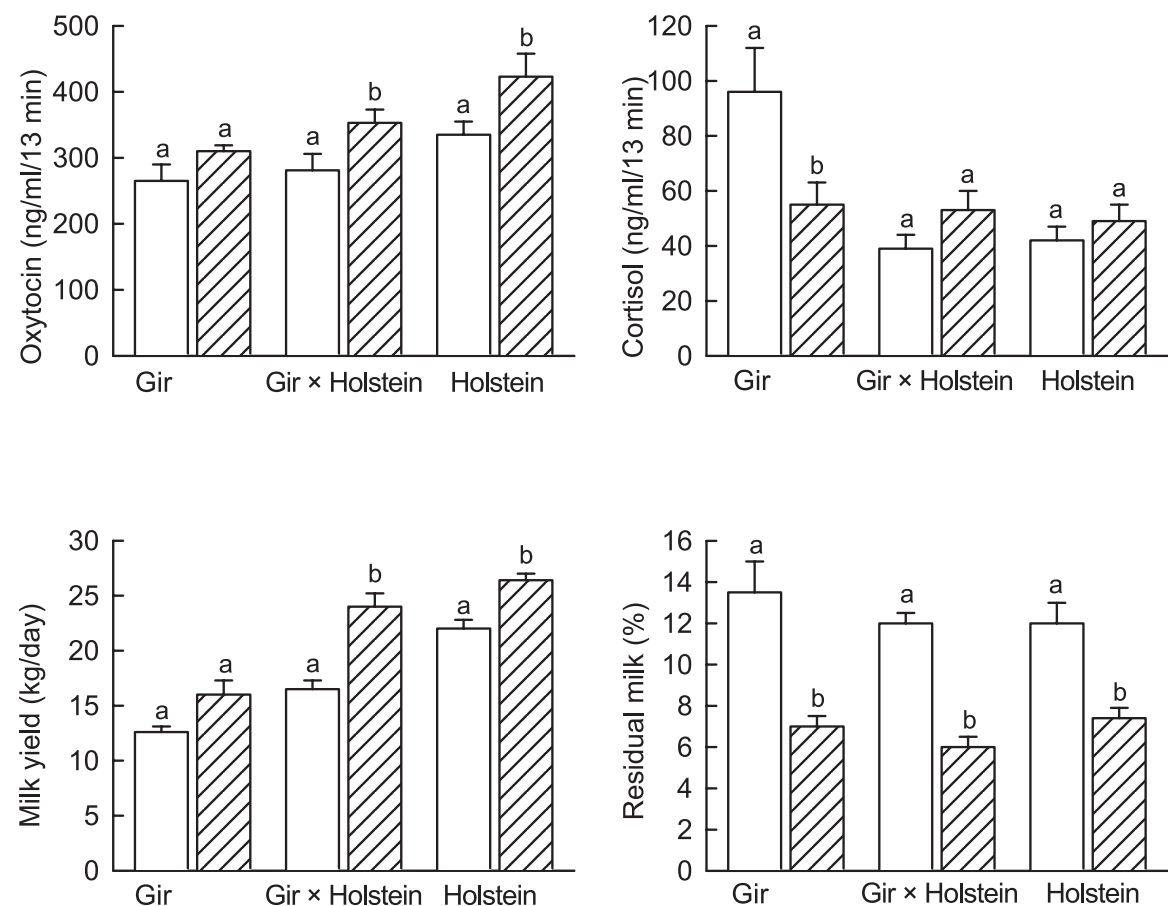

Figure 3. Total released oxytocin and cortisol, milk yield and percentage of residual milk (mean \pm standard error of the mean) measured during machine milking of Gir, Gir $\times$ Holstein and Holstein cows classified as impaired milk ejection (values of residual milk $>8 \%$ ) and effective milk ejection (values of residual milk $\leq 8 \%$ ). There were $5 / 6,3 / 6$ and $1 / 6$ cows classified as impaired milk ejection in the groups Gir, Gir $\times$ Holstein and Holstein, respectively. Means with different letters differ within group at $P<0.05$.

There were significant differences in average residual milk values between cows within groups. Consequently, when we classified the cows, within each group, based on their percentage of residual milk, we classified the cows into two groups: impaired milk ejection, cows that presented higher values of residual milk ( $>8 \%$ ); and effective milk ejection, cows that presented lower values of residual milk $(\leq 8 \%)$. It was possible to confirm the relationship between total OT release and milk yield in $\mathrm{Hol}$ and $\mathrm{Hol} / \mathrm{Gir}$ groups $(r=0.36, P=0.01 ; r=0.27, P=0.04$, respectively), and to observe that more milk ejection was positively associated to a greater OT release (Fig. 3). However, total CORT release was positively correlated with percentage of residual milk in the Gir group $(r=0.68, P=0.03)$.

However, the number of animals classed as impaired or effective milk ejection differed in each experimental group. Only one Holstein cow was classified as impaired milk ejection and presented a higher percentage of residual milk than the other five. In contrast, five Gir cows showed larger residual milk and only one Gir cow showed low residual milk. In the GirHol group three animals presented larger residual milk and the other three lower residual milk. 


\section{DISCUSSION}

As described in our results, the baseline levels of OT were affected by the group of cows. The Hol group had baseline levels of OT similar to those described in previous studies [20, 21]. Gir and GirHol cows had basal levels of OT above those for Hol cows and higher than those observed in the literature $[11,20]$. We have no explanation for this fact, but this higher level did not result from a conditioned release of OT because OT levels return to the same basal level at 13 min sampling and remained significantly higher than for the Hol group at this time. In contrast, all three groups showed similar basal levels of CORT, and these levels were comparable to those described by other authors [7, 20, 22].

During machine milking, all experimental groups had a significant increase in OT levels, as previously described by other authors studying cows considered to be well-adapted to milking, but OT profiles of the Gir and GirHol groups differed from those reported by other authors in Bos taurus [20, 23]. When comparing total OT release, Hol cows showed higher values than Gir cows although this difference was not significant, it could explain in part why Gir cows took longer to milk than Hol cows since milk flow has been demonstrated to be influenced by OT release which ensures milk ejection [23, 24].

However, morphological characteristics of the udder and teats may affect intramammary pression and milk flow [23, 24]. Although these characteristics were not measured in this study, it was observed that milk flow was high in Holstein, probably due to a lower resistance of the teat sphincter in comparison to the zebu breed which is usually milked with higher vacuum levels than Holstein cows (Negrão, personal communication). It is well known that Gir cows and their crossbred offspring have larger udder and teats when compared to Holstein cows $[25,26]$, but further studies on the relationships between udder and teat char- acteristics and milkability in different breeds are required.

In our study, total OT release did not differ between the three groups of cows but there was a significant and positive correlation between the total amounts of OT released and milk yield. Moreover, there was a relationship within groups between total OT release and milk yield, confirming that high OT levels are necessary for complete milk ejection [27, 28], and also that OT could act directly on mammary epithelial cells in intracellular transport and secretion as suggested by other authors [29].

During machine milking, Hol and GirHol groups showed CORT levels comparable with those described previously [20, 21]. In contrast, the Gir group showed higher CORT levels when compared to our other experimental groups and other references, both during and after milking [20]. In our study, CORT levels increased two or three times higher than basal levels for the Gir group. In addition, the total amount of CORT released for the Gir group was consistently higher than for the GirHol and Hol group. Similar increases in CORT levels have been reported during milking in Holstein cows only when stress is imposed by milking in unfamiliar surroundings [22].

Furthermore, the Gir group showed higher CORT levels when compared to the other experimental groups and to the literature $[13,20]$. A similar kind of CORT profile has been reported following stress imposed by weaning. However, CORT levels generally return to normal values three or four days after weaning $[7,8]$. This type of adaptation was not observed in the present study because CORT levels of the Gir group remained high in response to milking throughout the experiment.

The results concerning CORT response suggest that machine milking could be stressful for the Gir group and thus Gir cows could be less adapted to machine milking than Hol and GirHol groups. However, OT levels increased significantly during milking of the Gir group. Also, total OT release 
by group Gir and the percentage of residual milk did not differ from other experimental groups. Furthermore, within the Hol and HolGir groups, the cows that produced most milk during milking showed high levels of CORT.

Similar relationships between CORT and both milk yield and milk ejection have been observed in other studies [30, 31]. Moreover, some authors have reported that stress caused by first milkings following parturition or weaning is always accompanied by a lack of OT release and disturbed milk ejection [6-8], which was not recorded here.

Additionally, all experimental groups produced milk at levels comparable with those described by other authors [7, 20], and the Gir and GirHol groups did not exhibit a high percentage of residual milk as described for other zebu breeds [15] or for dairy cows submitted to different situations of stress [7,32] or during first milkings after parturition [6, 16]. This confirms that CORT levels alone are often poor predictors of stress in lactating animals as reported by other research [33] and suggests that, if stress exists in Gir cows, it is not very acute and only concerns some animals in the group. This low stress could result from the preliminary management from multipare animals with previous experience from exclusive machine milking as described in the materials and methods section.

In conclusion, all Gir cows showed higher levels of CORT release and a longer milking time than Holstein cows. However, under our conditions they, released enough OT, exhibited effective milk ejection and showed a lower percentage of residual milk than other stressed dairy cows. So, despite the reduced number of animals which limit the range of our conclusions, we believe that the Gir breed is not poorly adapted to machine milking, especially from a stimulatory and an endocrine point of view. Furthermore, within each of the three cow groups studied, there were individual cows characterised by a better milk production, a more complete and rapid milk ejection, a lower residual milk or higher milk flow rate than the others in the same group. Consequently, this variability makes it possible to identify and select Gir cows to ameliorate the pure breed or to improve adaptation of their crossbred offspring to machine milking rather than to change this local breed, well adapted to tropical climate, by the Holstein breed. Additionally, it would be necessary to optimize the machine milking settings for the Gir breed, which could also contribute to improving the Gir breed dairy performances.

\section{ACKNOWLEDGMENTS}

We are grateful to Jacques Portanguen and Sandra Letort from UMR INRA/ENSAR Production du lait (Rennes, France) for technical assistance and help with hormone analysis. The present experiment was funded by FAPESP.

\section{REFERENCES}

[1] Syrstad O. Heterosis in Bos taurus $\times$ Bos indicus crosses. Livest Prod Sci 1985, 12: 299-307.

[2] Syrstad O. Dairy cattle cross-breeding in the tropics: performance of secondary cross-bred populations. Livest Prod Sci 1989, 23: 97-106.

[3] Magnabosco C de U, Lobo RB, Bezerra LAF, Martinez ML. Estimate of genetic change in milk yield in a Gir herd in Brazil. Rev Bras Genet 1993, 16: 957-965.

[4] Souza EM, Milagres JC, Regazzi AJ, Martinez ML, Almeida e Silva M. Genetic and environmental effects on milk yield in Gir dairy herds. Rev Soc Bras Zootec 1996, 25: 889-901.

[5] Madalena FE. Experience with performance recording of dairy cattle in Brazil. International Committee for Animal Recording (ICAR) Technical Series. International Committee for Animal Recording (ICAR) 1998, 1: 235-246.

[6] Bruckmaier RM, Schams D, Blum JW. Aetiology of disturbed milk ejection in parturient primiparous cows. J Dairy Res 1992, 59: 479_ 489.

[7] Tancin V, Harcek L, Broucek J, Uhrincat M, Mihina S. Effect of suckling during early lactation and changeover to machine milking on plasma oxytocin and cortisol levels and milking characteristics in Holstein cows. J Dairy Res 1995, 62: 249-256. 
[8] Marnet PG, Negrão JA. The effect of a mixedmanagement system on the release of oxytocin, prolactin and cortisol in ewes during suckling and machine milking. Reprod Nutr Dev 2000, 40: 271-281.

[9] Sandoval-Castro CA, Anderson S, Leaver JD. Influence of milking and restricted suckling regimes on milk production and calf growth in temperate and tropical environments. Anim Sci 1999, 69: 287-296.

[10] Sandoval-Castro CA, Anderson S, Leaver JD. Production responses of tropical crossbred cattle to supplementary feeding and to different milking and restricted suckling regimes. Livest Prod Sci 2000, 66: 13-23.

[11] Negrão JA, Marnet PG. Effect of calf suckling on oxytocin, prolactin, growth hormone and milk yield in crossbred Gir $\times$ Holstein cows during milking. Reprod Nut Dev 2002, 42: 373-380.

[12] Tancin V, Kraetzl W-D, Schams D, Bruckmaier RM. The effects of conditioning to suckling, milking and of calf presence on the release of oxytocin in dairy cows. Appl Anim Behav Sci 2001, 72: 235-246.

[13] Lupoli B, Johansson B, Uvnäs-Morberg K, Svennersten-Sjaunja K. Effect of suckling on the release of oxytocin, prolactin, cortisol, gastrin, cholecystokinin, somatostatin and insulin in dairy cows and their calves. J Dairy Res 2001, 68: 175-187.

[14] Abubakar BY, Buvanendran V. Lactation curves of Friesian-Bunaji crosses in Nigeria. Livest Prod Sci 1981, 8: 11-19.

[15] Murugaiyah M, Ramakrishnan AR, Sheikh Omar AR, Knight CH, Wilde CJ. Lactation failure in crossbred Sahiwal Friesian cattle. J Dairy Res 2001, 68: 165-174.

[16] Negrão JA, Marnet PG, Kann G. Cortisol, adrenalin, noradrenalin and oxytocin release and milk yield during first milkings in primiparous ewes. Small Rumin Res 2003, 47: 69-75.

[17] National Research Council. Nutrient requirements of dairy cattle. 6th rev, Natl Acad Sci, Washington, 2001.

[18] Marnet PG, Volland H, Pradelles P, Grassi J, Beaufils M. Subpicogram determination of oxytocin by an enzyme immunoassay using acetylcholinesterase as label. J Immunoassay 1994, 15: 35-53.

[19] SAS/STAT. User's Guide, 4th ed Version 6, SAS Institute Inc, Cary, 1990.

[20] Gorewit RC, Svennersten K, Butler WR, Uvnas-Moberg K. Endocrine responses in cows milked by hand and machine. J Dairy Sci 1992, 75: 443-448.

[21] Bar-Peled U, Maltz E, Bruckmental I, Folman Y, Kali Y, Gacitua H, Lehrer AR. Relationship between frequent milking or suckling in early lactation and milk production of high producing dairy cows. J Dairy Sci 1995, 78 : 2726-2736.

[22] Bruckmaier RM, Schams D, Blum JW. Milk removal in familiar and unfamiliar surroundings: concentrations of oxytocin, prolactin, cortisol and endorfin. J Dairy Res 1993, 60: 449-456.

[23] Bruckmaier RM, Blum JW. Simultaneous recording of oxytocin release, milk ejection and milk flow during milking of dairy cows with and without prestimulation. J Dairy Res 1996, 63: 201-208.

[24] Pfeilsticker HU, Bruckmaier RM, Blum JW. Interruption of milking in dairy cows: effects on intramammary pressure and milking characteristics. J Dairy Res 1995, 62: 559-566.

[25] Teodoro RL, Verneque RS, Martinez ML, Cruz M, Paula LRO, Campos JP. Estudo de características do sistema mamário e suas relações com a produção de leite em vacas da raça Gir. Rev Soc Bras Zootec 2000, 29: 131135.

[26] Wensceslau AA, Lopes PS, Teodoro RL, Verneque RS, Euclydes RF, Ferreira WJ, Silva MA. Estimação de parâmetros genéticos de medidas de conformsção, produçã̃o de leite e idade ao primeiro parto em vacas da raça Gir leiteira. Rev Soc Bras Zootec 2000, 29: 153-158.

[27] Gorewit RC, Wachs EA, Sagi R, Merrill WG. Current concepts on the role of oxytocin in milk ejection. J Dairy Sci 1983, 66: 2236-2250.

[28] Schams D, Mayer H, Prokopp A, Worstorff H. Oxytocin secretion during milking in dairy cows with regard to the variation and importance of a threshold level for milk removal. J Endocrinol 1984, 102: 337-343.

[29] Lollivier V, Guinard-Flament J, OllivierBousquet M, Marnet PG. Oxytocin and milk removal: two important sources of variation in milk production and milk quality during and between milking. Reprod Nut Dev 2002, 42: 173-186.

[30] Mayer HK, Lefcourt AM. Failure of cortisol injected prior to milking to inhibit milk ejection in dairy-cattle. J Dairy Res 1985, 54: 173-177.

[31] Macuhova J, Tancin V, Kraezl WD, Meyer $\mathrm{HH}$, Bruckmaier RM. Inhibition of oxytocin release during repeated milking in unfamiliar surroundings: the importance of opioids and adrenal cortex sensitivity. J Dairy Res 2002, 69: 63-73.

[32] Rushen J, Munksgaard L, Marnet PG, DePassillé AM. Human contact and the effects of acute stress on cows at milking. Appl Anim Behav Sci 2001, 73: 1-14.

[33] Cook CJ. Oxytocin and prolactin suppress cortisol response to acute stress in both lactating and non-lactating sheep. J Dairy Res 1997, 64: $327-339$ 